\title{
Implementasi Manajemen Mutu Terpadu (Total QualityManagement) di Sekolah
}

\author{
Desi Ratna Yuli, Rusdinal, Hade Afriansyah \\ Universitas Negeri Padang \\ Indonesia \\ Email : desriratnayuliap@gmail.com
}

Abstrak- Quality is very important in education. We all admit, right now there are indeed problems in the education system. Middle school or college graduates are not ready to meet community needs. This problem affects the community. Anticipating changes that are so fast and the challenges that are getting bigger and more complex, there is no other way for the government to function as an organizer of development in the field of education and educational institutions to seek every means to increase the competitiveness of graduates and other academic products among others, achieved through improving the quality of education.

Keywords- management, quality, integrated, education, implementation

\section{Pendahuluan}

Manajemen Mutu Terpadu-MMT(Total Quality Management-TQM) merupakan suatu sistem nilai yang mendasar dan komperhensip dalam mengelola organisai dengan tujuan meningkatkan kinerja secara berkelanjutan dalam jangka panjang dengan memberikan perhatian secara khusus pada tercapainya kepuasan pelanggan dengan tetap memperhatikan secara memadai terhadap terpenuhinya kebutuhan seluruh stakeholders organisasi yang bersangkutan. Masalah peningkatan mutu dalam Manajemen Mutu Terpadu membutuhkan keterlibatan berbagai pihak terkait. Begitupun dalam dunia pendidikan. Tuntutan terhadap lulusan lembaga pendidikan yang bermutu semakin dibutuhkan karena semakin ketatnya persaingan dalam dunia kerja. Mengantisipasi perubahan-perubahan yang terjadi begitu cepat serta tantangan yang datang semakin besar dan kompleks, disini dibutuhkanlah keikutsertaan peran pemerintah dalam penyelenggaran pembangunan di bidang pendidikan supaya dapat mengupayakan segala cara untuk meningkatkan daya saing lulusan serta produk-produk akademik lainnya, yang mana dapat di capaiannya dengan meningkatkan mutu pendidikan.

\section{METODE PENELITIAN}

Artikel ini disusun dengan menggunakan metode kajian literatur, yang mana dalam penyusunannya artikel ini mengambil bahan- 
bahan dan merujuk pada berbagai sumber baik dari jurnal, buku dan juga sumber-sumber lainnya yang mendukung dalam bahasan dalam artikel ini.

Artikel ini disusun dengan sistematis dan terarah yang mana yang artikel ini dimulai dari bagaimana pentingnya pokok bahasan, dilanjutkan dengan membahas teori-teori yang berhubungan dengan bahasan artikel. Yang kemudian dari teoriteori yang di kumpulkan dari berbagai sumber tersebut di analisis dan dipelajari sehingga menghasilkan pengetahuan baru yang membahas pokok bahasan artikel tersebut.

\section{KAJIAN TEORI DAN PEMBAHASAN}

\section{A. Konsep Dasar Manajemen Mutu Terpadu}

Manajemen mutu terpadu merupakan sebagai perpaduan semua fungsi dari perusahaan ke sebuah falsafah holistic yang dibangun berdasarkan konsep kualitas team work, produktivitas dan pengertian serta kepuasaan pelanggan.

Konsep manajemen mutu terpadu pada dasarnya adalah menekankan pada kepuasan pelanggan dan pelayanan yang bermutu. Dalam dunia pendidikan yang saat ini berkembang begitu pesat sesuai dengan perkembangan zaman dan kebutuhan masyarakat maka, maka dari itu manfaat penerapan manajemen mutu terpadu merupakan perbaikan, pelayanan, penguragan biaya, dan kepuasan pelanggan. Perbaikan progresif dalam system manajemen dan kualitas pelayanan menghasilkan peningkatan kepuasan pelanggan.

Jadi dapat dipahami kepuasan pelanggan tergantung kualitas manajemen pelayanan yang di berikan suatu perusahaan atau lembaga tertentu. Kepuasan pelanggan tergantung kebutuhan yang di inginkankan oleh pelanggan itu sendiri.

Dalam kerangka manajemen pengembangan mutu terpadu, usaha pendidikan tidak lain adalah merupakan usaha "jasa" yang memberikan pelayanan kepada pelanggannya yang utamanya yaitu kepada mereka yang belajar dalam lembaga pendidikan tersebut. Para pelanggan layanan pendidikan dapat terdiri dari berbagai unsur paling tidak empat kelompoknya (Sallis, 1993).

\section{B. Manajemen Mutu Terpadu Dalam Pendidikan}

MMTP singkatan dari "Manajemen Mutu Terpadu Pendidikan. MMTP atau Manajemen Mutu Terpasu Pendidikan mencakup dua komponen yaitu : apa dan bagaimana menjalakan manajemen mutu terpadu pendidikan (MMTP).

MMTP/Manajemen Mutu Terpadu Pendidikan adalah totaliltas yang memerintahkan setiap orang dalam organisasi dilibatkan dalam upaya melakukan peningkatan atau perbaikan. Manajemen mutu terpadu pendidikan dapat diartikan sebagai setiap orang dalam lembaga apapun yang status, posisi, dan perannya adalah manajer dari tangggung jawab yang dimilikinya. 
Manajemen mutu terpadu pendidikan akan dijadikakn sebagai perubahan yang terus menerus hanya dapat dicapai oleh dan melalui seseorang. Manajemen mutu terpadu pendidikan sebuah pendekatan yang menjamin perubahan terus menerus atau permanen yang fokus pada sekolah dari kebijakn jangka pendek ke jangka panjang. Untuk mengembangkan budaya tersebut, tugas pertama Kepala Sekolah adalah memberikan kepercayaan kepada warga sekolah dan mendelegasikan kewenangan yang sesuai dengan stafnya turut bertanggungjawab terhadap peningkatan mutu.

\section{Pembahasan}

Dalam pelaksanaan MMTP membutuhkan pemimpinan yang kuat, disipin guru, staf tata usaha, dam peserta didik serta merupakan perubahan yang luar biasa. Pemimpin yang efektif seperti : memiliki penguasaan ilmu pengetahuan yang luas, bertanggung jawab, adil, jujur, memiliki kepribadian yang bagus agar kelak nanti tujuan yang sudah direncanakan dapat dicapai dan lainnya.

Peran kepalas sekolah dan wakil kepala sekolah adalah mendukung dan mengupayakan pendidikan bagi siswa dan stafnya pendukungnya. Kontrol bukanlah yang utama dalam manajemen mutu terpadu pendidikan. Sekolah yang menggunakan cara tradisional akan mengalami kesulitan dalam pengembangan karena kekakuan setiap keputusan. Biasanya, sekolah sering kekurangan program atau pemimpinya yang terlihat atau terkesan dengan otoriternya yang berbelit - belit. Sekolah seperti itu tidak akan tercapai nya suatu tujuan.

Maksud dari MMTP tersebut agar memberikan kesempatan kepala sekolah untuk mengubah cara tradisional menjadi sekolah yang menginginkan manajemen yang mutu tinggi. Untuk mencapainya harus ada seseorang yang memahami apa itu konsep mutu dan memiliki rancangan agar tercapainya tujuan.

Dalam pelaksanaan manajemen mutu terpadu pendidikan tidak luput dari hambatan. Pelaksanaan MMTP merupakan waktu yang relatif lama untuk mengadakan perubahan budaya mutu karena esensi dari MMTP ialah perubahan budaya. Hambatan penerapannya manajemen mutu terpadu pendidikan/MMTP, misalnya merasa cemas dengan ketidakpastian menerapkan sesuatu yang masih baru. Guru dan staf tidak berbuat yang terbaik karena mereka tidak dilibatkan dan pendapat - pendapatnya tidak di dengar.

Menurut Erra (Erra Yusmina, 2014)Sekolah dapat diartikan sebagai sebuah lembaga untukmelakukan proses belajar, mengajar, menurut tingkatan dan jurusannya. Terkait pendidikan kejuruan pada dasarnya memiliki variasi sesuai dengan subjektivitas pada perumusannya. Dalam rangka pengembangan atau 
peningkatan mutu sebuah sekolah, dapat dicapai melalui perencanaan dan program yang matang dengan mewujudkan visi dan misi serta menerapkanstrategi yang tepat.

Mutu produk pendidikan akan dipengaruhi oleh sejauh mana lembaga mampu mengelola seluruh potensi secara optimal mulai dari tenaga kependidikan, peserta didik, proses pembelajaran, sarana pendidikan, keuangan dan termasuk hubungannya dengan masyarakat. Pada kesempatan ini, lembaga pendidikan Islam harus mampu merubah paradigma baru pendidikan yang berorientasi pada mutu semua aktifitas yang berinteraksi didalamnya, seluruhnya mengarah pencapaian pada mutu.

MPMBS adalah sebuah singkatan dari Manajemen Peningkatan Mutu Berbasis Sekolah, yaitu sebagai model desentralisasi dalam bidang pendidikan, khususnya untuk pendidikan dasar dan menengah diyakini sebagai model yang akan mempermudah pencapaian tujuan pendidikan.

Pendekatan MPMBS, yaitu: "Pertama strategi pembangunan pendidikan selama ini lebih bersifat input oriented. Strategi yang demikian lebih bersandar pada asumsi bahwa bilamana semua input pendidikan telah dipenuhi, seperti penyediaan buku-buku (materi ajar) dan alat belajar lainnya, penyediaan sarana pendidikan, pelatihan guru dan tenaga kependidikan lainnya, maka secara otomatis lemabaga pendidikan (sekolah) akan dapat menghasilkan output (keluaran) yang bermutu sebagaimana yang diharapkan. Ternyata strategi input output yang diperkenalkan oleh teori "education production function. Tidak berfungsi sepenuhnya di lembaga pendidikan (sekolah) melainkan hanya terjadi dalam situasi ekonomi dan industri. Kedua pengelolaan pendidikan selama ini lebih bersifat macro -oriented, diatur oleh jajaran birokrasi ditingkat pusat.

Akibatnya banyak faktor yang diproyeksikan ditingkat makro (pusat) tidak terjadi atau tidak berjalan sebagaimana mestinya ditingkat mikro (sekolah) kompleksitasnya cakupan permasalahan pendidikan, seringkali tidak dapat terpikirkan secara utuh dan akurat oleh birokrasi pusat".

\section{KESIMPULAN}

MMTP ialah suatu sistem manajemen yang menyangkut mutu sebagai strategi usaha dan berorientasi pada kepuasan pelanggan dengan melibatkan seluruh anggota organisasi.MMTP adalah totalitas yang memerintahkan setiap orang dalam organisasi dilibatkan dalam upaya melakukan peningkatan atau perbaikan. MMTP diartikan sebagai setiap orang dalam lembaga apa pun yang status, posisi, dan perannya adalah manajer dari tanggung jawab yang dimilikinya. Manajemen mutu terpadu merupakan strategi pengelolaan mutu yang berusaha memenuhi harapan pelanggan yang dilakukan secara 
bertahap dan terus menerus untuk mencapai peningkatan mutu .

\section{Daftar Pustaka}

Afriansyah, H. (2019). MANAJEMEN MUTUTERPADU.1.http://doc.org/10. $\underline{17605 / O S F . I O / N R X H S}$

Agus Suwignyo, 2008. Pendidikan Tinggi \& Goncangan Perubahan. Yogyakarta: Pustaka Pelajar

Ahmad Tafsir, 2011. Ilmu Pendidikan Dalam Perspektif Islam. Bandung: PT. Remaja Rosdakarya

Sutrisno \& Muhyidin Albarobis, 2012. Pendidikan Islam Berbasis Problem Sosial. Jogjakarta: Ar-Ruzz Media

Husaini Usman, 2014. Manajemen Teori Praktik dan Riset Pendidikan. Jakarta: PT Bumi Aksara

Oemar Hamalik, 2010. Manajemen Pengembangan Kurikulum. Bandung: PT Remaja Rosdakarya.

Rusdinal, (2009). BUDAYA ORGANISASI PASCA PEMBANGUNAN DENGAN DUKUNGAN MANAJEMEN BERBASIS SEKOLAH. Pedagogi, 33(2). Retrived from http://journal.um.ac.id/index.php /ilmupendidikan/articlc/view/1200

Erra Yusmina. (2014). IMPLEMENTASI
MANAJEMEN MUTU TERPADU DALAM PENINGKATAN KINERJA SEKOLAH

PADA SMK NEGERI 1 BANDA ACEH.

Pedadogi, 4(2), 11. Retrieved from

http://www.jurnal.unsyiah.ac.id/JAP/article/v iew/2520/2367 